\title{
Operation Models in O2O Supply Chain When Existing Competitive Service Level
}

\author{
Jun Zhang ${ }^{\mathrm{a}, \mathrm{b}}$, Hong Chen ${ }^{\mathrm{a}}$ and Xiaozhi $\mathrm{Wu}^{\mathrm{a}}$ \\ ${ }^{\text {a }}$ School of Management and Economics \\ University of Electronic Science and Technology of China, Chengdu, China \\ ${ }^{\mathrm{b}}$ Logistics Engineering and Management Faculty \\ Kunming Metallurgy College, Kunming, China \\ zjun434@sina.com.cn
}

\begin{abstract}
O2O (Online to Offline) business model, a kind of new business model between online and offline channel, is put forward by some innovative enterprises. Supply chain decision under $\mathrm{O} 2 \mathrm{O}$ business model completely changes price competition in traditional dualchannel supply chains. Operation strategies in $\mathrm{O} 2 \mathrm{O}$ supply chains such as price discrimination and service free-riding have become important issues. When there exists different service level in $\mathrm{O} 2 \mathrm{O}$ supply chain, the corresponding parameters such as retail price, sales quantity, service level and total supply chain profit in three supply chain channels (vertical manufacturer's O2O supply chain, horizontal retailer's O2O supply chain and partially vertical manufacturer's O2O supply chain) are obtained and the corresponding performances are compared. The results show that the total supply chain profit in the vertical manufacturer's O2O supply chain is highest and the service level in the partially vertical manufacturer's O2O supply chain is highest. When there exists service competition in those three supply chains, the total supply chain profit in the horizontal retailer's $\mathrm{O} 2 \mathrm{O}$ supply chain is larger than that in the partially vertical manufacturer's $O 2 O$ supply chain. When there exists service free-riding, the total supply chain profit in the partially vertical manufacturer's O2O supply chain is larger than that in the horizontal retailer's O2O supply chain.
\end{abstract}

Keywords: $O 2 O$ supply chain, Equal channel price, Service competition, Service freeriding

\section{Introduction}

The e-commerce market grows rapidly in recent years. Europe is a mature e-commerce market and evolves constantly. The "e" in e-commerce is disappearing. There is no longer a separation between online retail and shopping at bricks-and-mortar shops because all purchases will be realized by omni-channel retailing [1]. According to statistics, ecommerce transactions in China will be $\$ 540$ billion in 2015 and Chinese e-commerce market will be larger than those of the US, Britain, Japan, Germany, and France combined in 2020 [22]. However, supply chain profits decrease gradually because of fierce competition in channel price. $\mathrm{O} 2 \mathrm{O}$ (Online to Offline) business model, a kind of new business combination model between online and offline channel, is put forward by some innovative enterprises. With the popularization of information technology, $\mathrm{O} 2 \mathrm{O}$ business model becomes localized and integrated with mobile devices at the end of 2013, which means a new era of $\mathrm{O} 2 \mathrm{O}$ business model is coming. Many manufacturers and retailers begin to integrate their supply chains by constructing their own online shops and offline experience shops. For example, Metersbonwe, a fashion manufacturer in China, improves consumer's shopping experience by constructing his online and offline shops. SAIC, an 
automobile manufacturing group in China, implements his $\mathrm{O} 2 \mathrm{O}$ business model by integrating his $4 \mathrm{~S}$ shops with the website, www.chexiang.com, a platform used to communicate with his consumers. Tmall, an e-commerce platform subordinated to Alibaba, begins to cooperate with Yintai Department Store in 2013. The examples mentioned above indicate that manufacturers and retailers attach great importance to $\mathrm{O} 2 \mathrm{O}$ business model. Suning, a giant retailer in China, adopts the same retail price both in online and offline channel, which completely change the traditional operation mode in the entire retail industry. From then on, some past physical stores become pure experience stores because their operating cost is high and online retail price is lower than offline retail price. When product's retail price in online channel is equal to that in offline channel, O2O business model turns into reality. Consumers can not only go shopping through online channel without going outdoors but also place an order after they try out the products they want to buy in physical stores.

Existing studies in $\mathrm{O} 2 \mathrm{O}$ business model mainly focus on recommendation system and how to improve online service. Empirical method and network algorithm are used in these studies. Some researches related to $\mathrm{O} 2 \mathrm{O}$ business model comes from studies in marketing. Empirical method is used in these studies. Examples in China are studied. Other branch of studies related to this paper comes from studies in dual-channel supply chain. There are lots of factors and problems studied in dual-channel supply chain, such as the impact of supply chain structure, how to coordinate dual-channel supply chain with different supply chain contracts, and government subsidy etc. However, there are few studies in $\mathrm{O} 2 \mathrm{O}$ supply chain. This study is based on the perspective of supply chain management. According to the $\mathrm{O} 2 \mathrm{O}$ business model in China, $\mathrm{O} 2 \mathrm{O}$ supply chain in this paper is defined as a special type of dual-channel supply chain in which the online and offline retail prices are the same. Three types of $\mathrm{O} 2 \mathrm{O}$ supply chain are put forward in this paper, and the corresponding parameters and supply chain performances are compared.

The remainder of this paper is organized as follows. Section 2 reviews the researches about $\mathrm{O} 2 \mathrm{O}$ business model and dual-channel supply chain. Benchmark model is established in Section 3. Vertical manufacturer's O2O supply chain, horizontal retailer's O2O supply chain and partially vertical manufacturer's O2O supply chain are optimized in Section 4, Section 5 and Section 6, respectively. Channel retail price, service level and supply chain profit in those three $\mathrm{O} 2 \mathrm{O}$ models are compared in Section 7. Section 8 summarizes this paper.

\section{Literature Review}

Some present studies in $\mathrm{O} 2 \mathrm{O}$ e-commerce model mainly focus on recommendation system and how to improve network service. Tsai (2013) finds that $\mathrm{O} 2 \mathrm{O}$ business model helps retailers to learn more about their customers through present social network data, and reflects current social e-commerce marketing trend [27]. Chen (2013) shows that the service improvement in recommendation system can increase the number of online consumer and consumers can buy products containing more service in offline channel [7]. Hsieh (2014) puts forward a BP neural network algorithm based on location, time, budget and other factors, which is used to match customer demand under $\mathrm{O} 2 \mathrm{O}$ business model [18].

Other researches related to $\mathrm{O} 2 \mathrm{O}$ business model come from studies in marketing. Grewal (2010) reviews studies about how to coordinate online and offline pricing strategy and gives some suggestions about future research under an organizational framework [16]. Scarpi, et al., (2014) compare the results between shopping for fun and shopping for need on word-of-mouth in online and offline channel [26]. Ellison (2006) examines three aspects of Internet retail demand based on data from memory module sales, which are taxes, geography and online-offline competition [14]. Garbarino (2006) investigates the effects of online pricing and offline pricing [15]. Du (2014) studies how to improve 
offline service quality under Chinese O2O business model [12]. Hong (2013) examines how to promote agricultural production and marketing by utilizing Quanzhou Agricultural $\mathrm{O} 2 \mathrm{O}$ E-Commerce Platform [17]. Shenyang O2O business model is investigated by Zhao (2014a) [33]. O2O business model in Wanda Group, a group in China, is analyzed by Zhao (2014b) [34].

Studies related to $\mathrm{O} 2 \mathrm{O}$ supply chain in this paper are mainly based on the studies in dual-channel supply chain, which are used to solve problems such as channel conflict, channel pricing decision and channel coordination etc. Choi (1996) studies a dual-channel supply chain, in which there exist duopoly manufacturers and duopoly common retailers [10]. Chiang (2003) establishes a dual-channel model which is based on utility theory and consumer demand model [9]. Tsay (2004) finds that adding electronic channel can increase supply chain members' profit [28]. Hua, et al., (2010) study the impact of distribution lead time commitment in electronic channel on manufacturer's and retailer's pricing strategies [19]. Dumrongsiri (2008) thinks that retailer's service improvement can increase overall profit in dual-channel supply chain [13]. Mukhopadhyay, et al., (2008) investigate how to coordinate a mixed supply chain with an optimal contract, where the retailer's cost information about adding value is asymmetric [24]. Cai (2010) studies the impact of dual-channel structure on manufacturer, retailer and the entire supply chain decision [3]. Chen (2012) designs a two-part tariff contract and a profit-sharing contract to coordinate a manufacturer Stackelberg dual-channel supply chain [5]. Cao, et al., (2013) examine how to design wholesale contract in a dual-channel supply chain where supply chain members' cost information is incomplete [4]. Huang, et al., (2012, 2013) consider how to deal with disruption management in a dual-channel supply chain when demand and cost disruption occur respectively [20, 21]. Ma, et al., (2013) studies how government's consumption-subsidy affects channel members' decisions in a dual-channel closed-loop supply chain [23]. Ryan, et al., (2013) investigate a dual-channel supply chain in which the demand in each channel is stochastic, and two supply chain contracts are used to coordinate the supply chain [25]. A two-way revenue-sharing contract used to coordinate a dual-channel supply chain is put forward by Xu, et al., (2014) when there exists product substitution in the two channels [31].

Customer-centered $\mathrm{O} 2 \mathrm{O}$ business model focuses on improving customer's shopping experience, which means that increased investment in service can increase consumer's demand. Researches concerning service in supply chain are as follows. Tsay (2000) studies a supply chain structure in which a manufacturer sells the same product to two retailers [29]. Service and retail price are used by the retailers to attract customers. Boyaci et al. (2004) consider two supply chains in which there exists customer service competition [2]. Three scenarios considering similar price are studied and compared by using game theory. They are coordinated scenario, uncoordinated scenario and hybrid scenario. Chen (2008) studies how the two-part tariff contract and revenue-sharing contract are used to coordinate a dual-channel supply chain in which there exists service competition [6]. Chen (2012) studies how a manufacturer builds and operates dualchannel supply chain in which there exists service competition [5]. Yan, et al., (2009) analyze the impact of retail service in dual-channel supply chain on channel competition, channel conflict and supply chain performance [32]. Wu (2012) studies a supply chain composed of two manufacturers and one retailer, in which there exist price and service competition between the products the manufacturers produced [30]. Dan, et al., (2012) discuss the impact of customer loyalty for traditional channel and retail service on pricing decisions among supply chain members [11]. The above studies mainly focus on decision problems in traditional supply chains.

As it can be seen from studies mentioned above, there are some researches about $\mathrm{O} 2 \mathrm{O}$ business model and how to coordinate dual-channel supply chains. However, there are few researches about pricing and service decision in dual-channel supply chain under $\mathrm{O} 2 \mathrm{O}$ business model. Therefore, the effect of service investment is analyzed in this paper, 
which may affect the demand in online and offline channel. Pricing and service decisions in three different supply chain modes are also obtained, which include vertical manufacturer's $\mathrm{O} 2 \mathrm{O}$ supply chain, horizontal retailer's $\mathrm{O} 2 \mathrm{O}$ supply chain and partially vertical manufacturer's $\mathrm{O} 2 \mathrm{O}$ supply chain.

\section{Basic Demand Model}

A two-stage $\mathrm{O} 2 \mathrm{O}$ supply chain is studied in this paper, in which a kind of perishable product is manufactured and sold. Suppose that the market demand is $a$, the percentage of the demand for online channel is $\phi(0<\phi<1)$, the unit production cost is $c_{m}$ and the channel retail price both in online and offline channel is $p$. There exist competition and cooperation in the two channels. The service level in online channel is $s_{e}$ and that in offline channel is $s_{t}$. The demand service substitution coefficient between the two channels is $\theta(-1<\theta<1)$. It means that there exists competition between the two channels when $\theta>0$ and there exists free-riding between the two channels when $\theta<0$. The cost function of investing in $\mathrm{O} 2 \mathrm{O}$ service is $C\left(s_{i}\right)=\eta s_{i}^{2} / 2,(i=e, t)$. The input coefficient, $\eta$, is large enough $\left(\eta>(1-\theta)^{2}\right)$. The demand function in the electronic channel and traditional channel is:

$$
\left\{\begin{array}{c}
q_{e}=\phi a-p+s_{e}-\theta s_{t} \\
q_{t}=(1-\phi) a-p+s_{t}-\theta s_{e}
\end{array} .\right.
$$

\section{Mode I: Vertical Manufacturer's O2O Supply Chain}

Vertical manufacturer's $\mathrm{O} 2 \mathrm{O}$ supply chain refers to implementing $\mathrm{O} 2 \mathrm{O}$ business in vertical manufacturer's dual-channel supply chain. Its nature is centralized decision in manufacturer's dual-channel supply chain, in which the channel retail price in online channel is equal to that in offline channel and service level is improved in both channel. Some manufacturers in China such as TCL, Metersbonwe and Septwolves operate their own online and offline shops, which can meet consumers' demand in different channels. The decisions under vertical manufacturer's $\mathrm{O} 2 \mathrm{O}$ model are centralized decisions. Thus, the supply chain profit function is written as

$$
\Pi=\left(p-c_{m}\right)\left[a-2 p+(1-\theta)\left(s_{e}+s_{t}\right)\right]-\frac{\eta}{2}\left(s_{e}^{2}+s_{t}^{2}\right) .
$$

The Hessian matrix of $\Pi$ with respect to $p, s_{e}$ and $s_{t}$ is $H=\left[\begin{array}{ccc}-4 & 1-\theta & 1-\theta \\ 1-\theta & -\eta & 0 \\ 1-\theta & 0 & -\eta\end{array}\right]$. Its order principal minor determinant is $\left[-4,4 \eta-(1-\theta)^{2},-4 \eta^{2}+2 \eta(1-\theta)^{2}\right]$, which shows that $H$ is a negative definite matrix. Therefore, $\Pi\left(p, s_{e}, s_{t}\right)$ is a strictly differential concave function.

By solving the first-order condition, $\partial \Pi / \partial p=\partial \Pi / \partial s_{e}=\partial \Pi / \partial s_{t}=0$, we obtain that the optimal retail price and the optimal service level are

the sales quantities in the two channels are

$$
\left\{\begin{array}{l}
p^{*}=c_{m}+\frac{\eta\left(a-2 c_{m}\right)}{4 \eta-2(1-\theta)^{2}}, \\
s_{e}^{*}=s_{t}^{*}=\frac{(1-\theta)\left(a-2 c_{m}\right)}{4 \eta-2(1-\theta)^{2}}
\end{array}\right.
$$

$$
\left\{\begin{array}{l}
q_{e}^{*}=\frac{a\left[\eta(4 \phi-1)+(1-2 \phi)(1-\theta)^{2}\right]-2 \eta c_{m}}{4 \eta-2(1-\theta)^{2}}, \\
q_{t}^{*}=\frac{a\left[\eta(3-4 \phi)+(2 \phi-1)(1-\theta)^{2}\right]-2 \eta c_{m}}{4 \eta-2(1-\theta)^{2}},
\end{array}\right.
$$


the total sales quantity is $Q^{*}=\frac{\eta\left(a-2 c_{m}\right)}{2 \eta-(1-\theta)^{2}}$, and the total supply chain profit is $\Pi^{*}=\frac{\eta\left(a-2 c_{m}\right)^{2}}{8 \eta-4(1-\theta)^{2}}$.

\section{Mode II: Horizontal Retailer's O2O Supply Chain}

Horizontal retailer's $\mathrm{O} 2 \mathrm{O}$ supply chain refers to implementing $\mathrm{O} 2 \mathrm{O}$ business in horizontal retailer's dual-channel supply chain. As far as traditional retailers are concerned, $\mathrm{O} 2 \mathrm{O}$ business is used to compete against the impact of e-commerce. Offline experience shops established by online retailers are used to attract their customers. Giant retailers in China such as Yintai Department Store, YHD and Suning begin to implement horizontal retailer's $\mathrm{O} 2 \mathrm{O}$ business model. In order to implement $\mathrm{O} 2 \mathrm{O}$ business model, channel retail price both in online and offline channels must be the same and service level can be improved, which can, in turn, attract more customers.

The retailers control the sales channels in horizontal retailer's $\mathrm{O} 2 \mathrm{O}$ supply chain and they are always giant retailers. They are also the dominant parties in the game among supply chain members. Therefore, we assume that the game in the horizontal retailer's $\mathrm{O} 2 \mathrm{O}$ supply chain is a retailer-dominant Stackelberg game.

The retailer's profit function is

$$
\Pi_{r}^{0}=(p-w)\left(q_{e}+q_{t}\right)-\frac{\eta}{2}\left(s_{e}^{2}+s_{t}^{2}\right) .
$$

The manufacturer's profit function is

$$
\Pi_{m}^{0}=\left(w-c_{m}\right)\left(q_{e}+q_{t}\right) .
$$

Based on the leader-follower game theory, the retailer offers its marginal profit and service level according to the market demand at first. The manufacturer provides the retailer with the products. The wholesale price in this case is above the manufacturer's production cost. According to the retailer-dominant model (Choi, 1996), the channel retail price is $p=w+m$, where $m$ is the retailer's unit marginal profit.

The response function of the manufacturer's wholesale price with respect to the retailer's marginal profit and service level is

$$
w\left(m, s_{e}, s_{t}\right)=\frac{1}{4}\left[a+2\left(c_{m}-m\right)+(1-\theta)\left(s_{e}+s_{t}\right)\right] \cdot
$$

By substituting Eq. (5) into Eq. (3), the decentralized decision in the horizontal retailer's $\mathrm{O} 2 \mathrm{O}$ mode is made. The strategies are as follows.

The retailer's marginal profit and service level are

$$
\left\{\begin{array}{c}
m^{0}=\frac{\eta\left(a-2 c_{m}\right)}{4 \eta-(1-\theta)^{2}} \\
s_{e}^{0}=s_{t}^{0}=\frac{(1-\theta)\left(a-2 c_{m}\right)}{2\left[4 \eta-(1-\theta)^{2}\right]} .
\end{array}\right.
$$

The wholesale price and retail price are

$$
\left\{\begin{array}{l}
w^{0}=c_{m}+\frac{\eta\left(a-2 c_{m}\right)}{2\left[4 \eta-(1-\theta)^{2}\right]} \\
p^{0}=c_{m}+\frac{3 \eta\left(a-2 c_{m}\right)}{2\left[4 \eta-(1-\theta)^{2}\right]} .
\end{array}\right.
$$

The channel sales quantity is

$$
\left\{\begin{array}{l}
q_{e}^{0}=\frac{a\left[(1-\theta)^{2}(1-2 \phi)-\eta(3-8 \phi)\right]-2 \eta c_{m}}{2\left[4 \eta-(1-\theta)^{2}\right]} \\
q_{t}^{0}=\frac{a\left[(1-\theta)^{2}(1-2 \phi)+\eta(5-8 \phi)\right]-2 \eta c_{m}}{2\left[4 \eta-(1-\theta)^{2}\right]}
\end{array} .\right.
$$

The total sales quantity is $Q^{0}=q_{e}^{0}+q_{t}^{0}=\frac{\eta\left(a-2 c_{m}\right)}{4 \eta-(1-\theta)^{2}}$. 
The total supply chain profit is $\Pi^{0}=\frac{\eta\left[6 \eta-(1-\theta)^{2}\right]\left(a-2 c_{m}\right)^{2}}{4\left[4 \eta-(1-\theta)^{2}\right]^{2}}$.

\section{Mode III: Partially Vertical Manufacturer's O2O Supply Chain}

Partially vertical manufacturer's $\mathrm{O} 2 \mathrm{O}$ supply chain refers to implementing an operation strategy combined with $\mathrm{O} 2 \mathrm{O}$ business model in traditional dual-channel supply chain. It means that the manufacturer implement the operation strategy that the channel retail price in online channel is equal to that in offline channel. However, customers can go shopping in the online channel or the offline channel according to their preferences. The service level in the two channels is different. Although the channel managers in this mode are still traditional manufacturer and traditional retailer, cooperation in $\mathrm{O} 2 \mathrm{O}$ business model can be realized under the same channel retail price. Tmall, the giant e-retailer in China, breaks the business gap between the online and offline channel in its "double-eleven" promotion, and integrates 30,000 offline stores throughout more than 1,000 counties in China, 2013. United promotion is realized in the online and offline shops. Manufacturers' cooperation with traditional retailers is also a new type of business model in $\mathrm{O} 2 \mathrm{O}$ era.

The manufacturer controls the online channel and the retailer controls the offline channel in partially vertical manufacturer's $\mathrm{O} 2 \mathrm{O}$ model. The manufacturer in this model is always in an advantage position. Thus, we assume that the game in the partially vertical manufacturer's O2O supply chain is a manufacturer-dominant Stackelberg game.

There is only one channel retail price, one of the decision variables which must be determined during the course of the manufacturer's decision making in the $\mathrm{O} 2 \mathrm{O}$ supply chain. The decision is made as follows. The manufacturer determines the wholesale price and the online service level, and the retailer determines the purchase quantity and the offline service level. The retailer determines the retail price, $p$, and the manufacturer follows the decision the retailer makes. The related analysis is shown below.

The retailer's profit function is

$$
\Pi_{r}^{1}=(p-w) q_{t}-\eta s_{t}^{2} / 2 .
$$

By solving $\partial \Pi_{r}^{1} / \partial p=\partial \Pi_{r}^{1} / \partial s_{t}=0$, the retailer's response functions with respect to $w$ and the manufacturer's channel retail price are

$$
\left\{\begin{array}{c}
p\left(w, s_{e}\right)=\frac{a \eta(1-\phi)+(\eta-1) w-\eta \theta s_{e}}{2 \eta-1} . \\
s_{t}\left(w, s_{e}\right)=\frac{(1-\phi) a-w-\theta s_{e}}{2 \eta-1}
\end{array} .\right.
$$

By substituting Eq. (7) into the manufacturer's profit function, we obtain that

$$
\Pi_{m}^{1}=\left(p-c_{m}\right) q_{e}+\left(w-c_{m}\right) q_{t}-\eta s_{e}^{2} / 2 .
$$

By solving $\partial \Pi_{m}^{1} / \partial w=\partial \Pi_{m}^{1} / \partial s_{e}=0$, the manufacturer's response functions with respect to $w$ and $s_{e}$ in the decentralized O2O supply chain are

$$
\left\{\begin{array}{c}
w^{1}=\frac{c_{m}\left[4 \eta^{3}+\eta(2-\theta)^{2}(1+\theta)-\left(1-\theta^{2}\right)^{2}-2 \eta^{2}\left(3-\theta-\theta^{2}\right)\right]+a \eta\left[2 \phi \eta^{2}-1+\theta+\theta^{2}+(1-\theta)\left(2-\theta^{2}\right) \phi+\eta\left(2+\theta-5 \phi+\phi \theta^{2}\right)\right]}{6 \eta^{3}-\eta^{2}(1-\theta)(7+3 \theta)-\left(1-\theta^{2}\right)^{2}+2 \eta\left[2-(1-\theta) \theta^{2}\right]} . \\
s_{e}^{1}=\frac{c_{m}\left[3 \eta\left(1-\theta^{2}\right)-4 \eta^{2}-(1-\theta)(1+\theta)^{2}\right]+a\left[3 \eta^{2}-\eta+\theta-\eta \theta+3 \eta^{2} \theta+2 \eta \theta^{2}-\theta^{3}-\phi(2 \eta+\theta-1)\left(1+\eta+3 \eta \theta-\theta^{2}\right)\right]}{6 \eta^{3}-\eta^{2}(1-\theta)(7+3 \theta)-\left(1-\theta^{2}\right)^{2}+2 \eta\left[2-(1-\theta) \theta^{2}\right]}
\end{array}\right.
$$

Then, the retailer's corresponding response functions are

$$
\left\{\begin{array}{c}
p^{1}=\frac{c_{m}\left[2 \eta^{3}-\eta^{2}(1-\theta)(4+\theta)+\eta(1+\theta)\left(3-4 \theta+2 \theta^{2}\right)-\left(1-\theta^{2}\right)^{2}\right]+a \eta\left[\theta+\eta^{2}(3-2 \phi)+(1-\theta) \phi+\eta(-1+\theta)(1+\phi+2 \phi \theta)\right]}{6 \eta^{3}-\eta^{2}(1-\theta)(7+3 \theta)-\left(1-\theta^{2}\right)^{2}+2 \eta\left[2-(1-\theta) \theta^{2}\right]} . \\
s_{t}^{1}=\frac{c_{m}\left[\eta\left(2+\theta-\theta^{2}\right)-2 \eta^{2}-(1-\theta)(1+\theta)^{2}\right]+a\left[\eta^{2}(3-4 \phi)+\left(1-\theta^{2}\right)(1+\phi \theta-\phi)-3 \eta+\left(4-\theta+\theta^{2}\right) \phi \eta\right]}{6 \eta^{3}-\eta^{2}(1-\theta)(7+3 \theta)-\left(1-\theta^{2}\right)^{2}+2 \eta\left[2-(1-\theta) \theta^{2}\right]}
\end{array} .\right.
$$

The corresponding channel sales quantities are 


$$
\left\{\begin{array}{c}
q_{e}^{1}=\frac{a \eta(1+\theta)[2 \theta+\phi(2-\theta)(1-\theta)-1]+a \eta^{2}[4-\theta-8 \phi+\phi \theta(3+\theta)]-\eta c_{m}\left[2 \eta^{2}+\eta \theta(1+\theta)+\theta(1+\theta)^{2}\right]-a \eta^{3}(3-8 \phi)}{2 \eta\left[2-(1-\theta) \theta^{2}\right]+6 \eta^{3}-\eta^{2}(1-\theta)(7+3 \theta)-\left(1-\theta^{2}\right)^{2}} . \\
q_{t}^{1}=\frac{\eta c_{m}\left[\eta\left(2+\theta-\theta^{2}\right)-2 \eta^{2}-(1-\theta)(1+\theta)^{2}\right]+a \eta\left[\eta^{2}(3-4 \phi)+\left(1-\theta^{2}\right)(1-\phi+\phi \theta)+\eta(4 \phi-3)-(1-\theta) \phi \theta \eta\right]}{2 \eta\left[2-(1-\theta) \theta^{2}\right]+6 \eta^{3}-\eta^{2}(1-\theta)(7+3 \theta)-\left(1-\theta^{2}\right)^{2}}
\end{array} .\right.
$$

The total sales quantity is

$$
Q^{1}=\frac{a \eta\left[\left(4 \eta^{2}+1\right) \phi+\theta(1+\theta-\theta \phi)+\eta(1-\theta)(1-4 \phi-2 \phi \theta)\right]-\eta c_{m}\left[(1+\theta)^{2}+2 \eta\left(2 \eta+\theta^{2}-1\right)\right]}{2 \eta\left[2-(1-\theta) \theta^{2}\right]+6 \eta^{3}-\eta^{2}(1-\theta)(7+3 \theta)-\left(1-\theta^{2}\right)^{2}} .
$$

\section{Comparison among Decisions in the Three O20 Supply Chains}

The decisions made in the three $\mathrm{O} 2 \mathrm{O}$ supply chains are compared in this section, and some numerical examples are also used to illustrate the corresponding results.

Compared with the other two O2O supply chain models in this paper, the total supply chain profit in the vertical manufacturer's $\mathrm{O} 2 \mathrm{O}$ model is highest because of its integrated operation. Centralized operation in retail channels is implemented in the horizontal retailer's $\mathrm{O} 2 \mathrm{O}$ supply chain. Centralized pricing decision is implemented in partially vertical manufacturer's $\mathrm{O} 2 \mathrm{O}$ supply chain. The decisions in the three $\mathrm{O} 2 \mathrm{O}$ models are compared in Table 1.

As is shown in the table, the service level in horizontal retailer's $\mathrm{O} 2 \mathrm{O}$ supply chain is lower than that in vertical manufacturer's $\mathrm{O} 2 \mathrm{O}$ supply chain and the sales quantity in horizontal retailer's $\mathrm{O} 2 \mathrm{O}$ supply chain is smaller than that in vertical manufacturer's $\mathrm{O} 2 \mathrm{O}$ supply chain. However, the channel retail price in the former model is larger than that in the latter model. Nmerical examples are used to illustrate the results shown in Table 1because the strategies in Mode III are more complex than those in the other two modes.

\section{Table 1. Comparison of Decision Variables (DV) in the Three O2O Models}

\begin{tabular}{cccc}
\hline DV & Mode I & Mode II & Mode III \\
\hline$p$ & $c_{m}+\frac{\eta\left(a-2 c_{m}\right)}{4 \eta-2(1-\theta)^{2}}$ & $c_{m}+\frac{3 \eta\left(a-2 c_{m}\right)}{2\left[4 \eta-(1-\theta)^{2}\right]}$ & $\frac{c_{m}\left[2 \eta^{3}-\eta^{2}(1-\theta)(4+\theta)+\eta(1+\theta)\left(3-4 \theta+2 \theta^{2}\right)-\left(1-\theta^{2}\right)^{2}\right]+a \eta\left[\theta+\eta^{2}(3-2 \phi)+\phi(1-\theta)+\eta(-1+\theta)(1+\phi+2 \phi \theta)\right]}{6 \eta^{3}-\eta^{2}(1-\theta)(7+3 \theta)-\left(1-\theta^{2}\right)^{2}+2 \eta\left[2-(1-\theta) \theta^{2}\right]}$ \\
$w$ & - & $c_{m}+\frac{\eta\left(a-2 c_{m}\right)}{2\left[4 \eta-(1-\theta)^{2}\right]}$ & $\frac{c_{m}\left[4 \eta^{3}+\eta(2-\theta)^{2}(1+\theta)-\left(1-\theta^{2}\right)^{2}-2 \eta^{2}\left(3-\theta-\theta^{2}\right)\right]+a \eta\left[2 \phi \eta^{2}-1+\theta+\theta^{2}+\phi(1-\theta)\left(2-\theta^{2}\right)+\eta\left(2+\theta-5 \phi+\phi \theta^{2}\right)\right]}{6 \eta^{3}-\eta^{2}(1-\theta)(7+3 \theta)-\left(1-\theta^{2}\right)^{2}+2 \eta\left[2-(1-\theta) \theta^{2}\right]}$ \\
$S_{e}$ & $\frac{(1-\theta)\left(a-2 c_{m}\right)}{4 \eta-2(1-\theta)^{2}}$ & $\frac{(1-\theta)\left(a-2 c_{m}\right)}{2\left[4 \eta-(1-\theta)^{2}\right]}$ & $\frac{c_{m}\left[3 \eta\left(1-\theta^{2}\right)-4 \eta^{2}-(1-\theta)(1+\theta)^{2}\right]+a\left[3 \eta^{2}-\eta+\theta-\eta \theta+3 \eta^{2} \theta+2 \eta \theta^{2}-\theta^{3}-\phi(2 \eta+\theta-1)\left(1+\eta+3 \eta \theta-\theta^{2}\right)\right]}{6 \eta^{3}-\eta^{2}(1-\theta)(7+3 \theta)-\left(1-\theta^{2}\right)^{2}+2 \eta\left[2-(1-\theta) \theta^{2}\right]}$ \\
$\boldsymbol{S}_{t}$ & $\frac{(1-\theta)\left(a-2 c_{m}\right)}{4 \eta-2(1-\theta)^{2}}$ & $\frac{(1-\theta)\left(a-2 c_{m}\right)}{2\left[4 \eta-(1-\theta)^{2}\right]}$ & $\frac{c_{m}\left[\eta\left(2+\theta-\theta^{2}\right)-2 \eta^{2}-(1-\theta)(1+\theta)^{2}\right]+a\left[\eta^{2}(3-4 \phi)+\left(1-\theta^{2}\right)(1+\phi \theta-\phi)-3 \eta+\left(4-\theta+\theta^{2}\right) \phi \eta\right]}{6 \eta^{3}-\eta^{2}(1-\theta)(7+3 \theta)-\left(1-\theta^{2}\right)^{2}+2 \eta\left[2-(1-\theta) \theta^{2}\right]}$ \\
$Q$ & $\frac{\eta\left(a-2 c_{m}\right)}{2 \eta-(1-\theta)^{2}}$ & $\frac{\eta\left(a-2 c_{m}\right)}{4 \eta-(1-\theta)^{2}}$ & $\frac{a \eta\left[\left(4 \eta^{2}+1\right) \phi+\theta(1+\theta-\theta \phi)+\eta(1-\theta)(1-4 \phi-2 \phi \theta)\right]-\eta c_{m}\left[(1+\theta)^{2}+2 \eta\left(2 \eta+\theta^{2}-1\right)\right]}{2 \eta\left[2-(1-\theta) \theta^{2}\right]+6 \eta^{3}-\eta^{2}(1-\theta)(7+3 \theta)-\left(1-\theta^{2}\right)^{2}}$ \\
\hline
\end{tabular}

Suppose that the market scale of a product is $a=100$, the percentage of the demand for online channel is $\phi=0.4$, the cost coefficient of service investment is $\eta=4$, and the unit production cost is $c_{m}=10$. The service substitution coefficient between the online and offline channels, $\theta$, is the independent variables. It ranges from -0.3 to 0.3 . The retail price, service level, total sales quantity and total supply chain profit in the three $\mathrm{O} 2 \mathrm{O}$ modes are shown in Figure 1-4, respectively. 


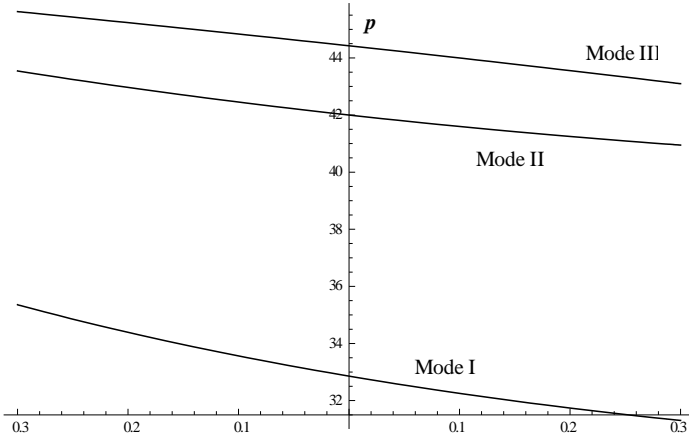

Mode I: Vertical manufacturer's $\mathrm{O} 2 \mathrm{O}$ supply chain Mode II: Horizontal retailer's O2O supply chain Mode III: Partially vertical manufacturer's O2O supply chain

Figure 1. Comparison of the Channel Retail Price in the Three Modes

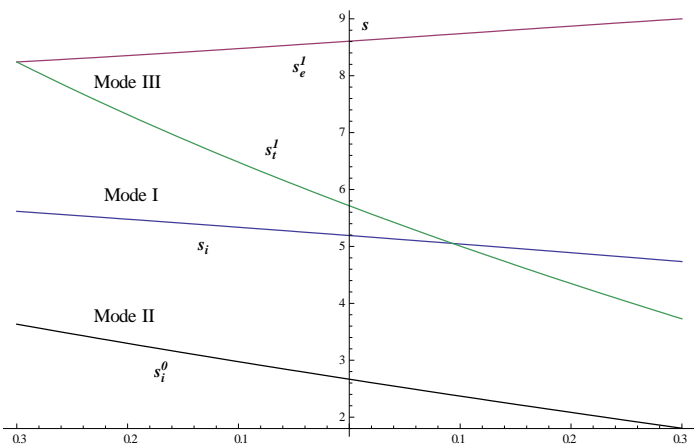

Mode I: Vertical manufacturer's O2O supply chain Mode II: Horizontal retailer's O2O supply chain Mode III: Partially vertical manufacturer's O2O supply chain

Figure 2. Comparison of the Service Level in the Three Modes

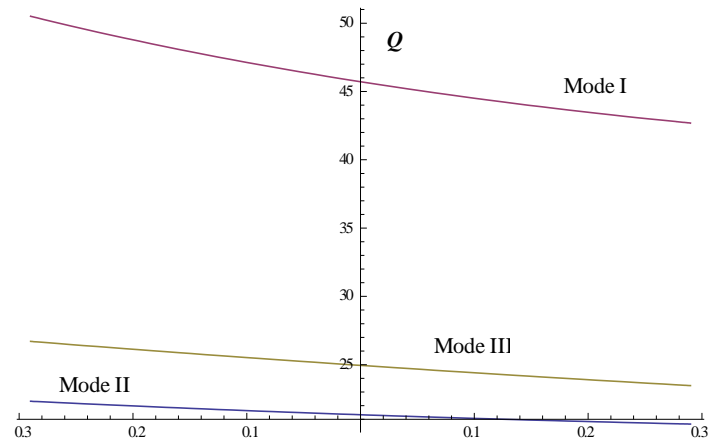

Mode I: Vertical manufacturer's $\mathrm{O} 2 \mathrm{O}$ supply chain Mode II: Horizontal retailer's O2O supply chain Mode III: Partially vertical manufacturer's O2O supply chain

Figure 3. Comparison of the Total Sales Quantity in the Three Modes

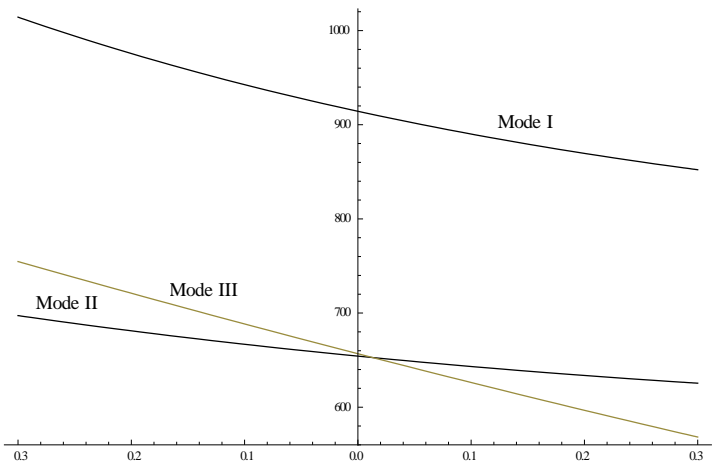

Mode I: Vertical manufacturer's O2O supply chain Mode II: Horizontal retailer's O2O supply chain

Mode III: Partially vertical manufacturer's O2O supply chain

\section{Figure 4. Comparison of the Total Supply Chain Profit in the Three Modes}

As can be seen from Figure 1, the channel retail price in Mode I is lowest and that in Mode III is highest. The channel retail price in Mode II is between that in Mode I and Mode III. The retail price in the three $\mathrm{O} 2 \mathrm{O}$ modes decreases in $\theta$. As is shown in Figure 
2, the service level in Mode III is highest and the service level in Mode I is lower than that in Mode III. The service level in Mode II is lowest. The service level in the three $\mathrm{O} 2 \mathrm{O}$ modes decreases in $\theta$ except that the online service level in Mode III increases in $\theta$. The result shows that competition takes an active role in improving the retailer's service level. As it can be seen from Figure 3, the total sales quantity in Mode I is greatest and the total sales quantity in Mode III is less than that in Mode I. The total sales quantity in Mode II is smallest, which is related to the lowest service level in this mode. The total sales quantity in the three $\mathrm{O} 2 \mathrm{O}$ modes also decreases in $\theta$. Last but not least, the total supply chain profit in Mode I is highest, which can be seen in Figure 4. The total supply chain profit in Mode II is higher than that in Mode III when there exists competition in the channel service level $(\theta>0)$. The supply chain profit in Mode III is higher than that in Mode II when there exists free-riding in the service level $(\theta<0)$. The total supply chain profit in the three $\mathrm{O} 2 \mathrm{O}$ modes also decreases in $\theta$.

\section{Conclusions}

With the spread of $\mathrm{O} 2 \mathrm{O}$ business model, manufacturers and retailers are committed to provide consumers with better shopping experience. Whether consumers go shopping in the online channel or go shopping in the offline channel depends on channel service level. Three types of $\mathrm{O} 2 \mathrm{O}$ supply chain based on service competition such as vertical manufacturer's $\mathrm{O} 2 \mathrm{O}$ supply chain, horizontal retailer's $\mathrm{O} 2 \mathrm{O}$ supply chain and partially vertical manufacturer's O2O supply chain are commonly seen in business world and are studied in this paper. The decisions in these $\mathrm{O} 2 \mathrm{O}$ supply chains with the same channel retail price and service substitution are compared. The channel retail price, service level, sales quantity and total supply chain profit in each mode are also obtained. The results illustrate that $\mathrm{O} 2 \mathrm{O}$ supply chain profit can be maximized in vertical manufacturer's $\mathrm{O} 2 \mathrm{O}$ supply chain, and the channel service level in partially vertical manufacturer's O2O supply chain is higher than that in horizontal retailer's $\mathrm{O} 2 \mathrm{O}$ supply chain when making decentralized decision.

Research on $\mathrm{O} 2 \mathrm{O}$ supply chain is a new field for enterprises and scholars worldwide. There are many interesting problems worth studying besides the modes in this paper. For example, with the development of $\mathrm{O} 2 \mathrm{O}$ business model, there are other types of $\mathrm{O} 2 \mathrm{O}$ supply chain need to be studied such as closed-loop O2O supply chain. There are other factors in $\mathrm{O} 2 \mathrm{O}$ supply chain which can be studied such as advertisement, subsidy and inventory management etc. How to coordinate $\mathrm{O} 2 \mathrm{O}$ supply chain with new types of contract is also an interesting problem.

\section{Conflict of Interests}

The authors declare that there is no conflict of interests regarding the publication of this paper.

\section{Acknowledgement}

This research was supported by National Natural Science Foundation of China (No.71472026) and Research Fund for the Doctoral Program of Higher Education of China (No. 20110185110022).

\section{References}

[1] Amanda, "China E-Commerce Market to Reach 30 Trillion Yuan in 2020", China Internet Watch, (2013) March 13

[2] T. Boyaci and G. Gallego, "Supply chain coordination in a market with customer service competition", Production and Operations Management, vol. 1, no. 13, (2004). 
[3] G. G. Cai, "Channel selection and coordination in dual-channel supply chains", Journal of Retailing, vol 1 , no. 86, (2010).

[4] E. Cao, "Contracting with asymmetric cost information in a dual-channel supply chain", Operations Research Letters, vol. 4, no. 41, (2013).

[5] J. Chen, H. Zhang and Y. Sun, "Implementing coordination contracts in a manufacturer Stackelberg dual-channel supply chain", Omega, vol. 5, no. 40, (2012).

[6] K.-Y. Chen, M. Kaya and Ö. Özer, "Dual sales channel management with service competition", Manufacturing \& Service Operations Management, vol. 4, no. 10, (2008).

[7] Y.-C. Chen and H.-C. Hsieh, "Improved Precision Recommendation Scheme by BPNN Algorithm in O2O Commerce", IEEE 10th International Conference on e-Business Engineering, (2013) September 11-13, Coventry, United Kingdom.

[8] W. K. Chiang and G. E. Monahan, "Managing inventories in a two-echelon dual-channel supply chain", European Journal of Operational Research, vol. 2, no. 162, (2005).

[9] W. K. Chiang, D. Chhajed and J. D. Hess, "Direct marketing, indirect profits: A strategic analysis of dual-channel supply-chain design", Management Science, vol. 1, no. 49, (2003).

[10] S. C. Choi, "Price competition in a duopoly common retailer channel", Journal of Retailing, vol. 2, no. 72, (1996).

[11] B. Dan, G. Xu and C. Liu, "Pricing policies in a dual-channel supply chain with retail services", International Journal of Production Economics, vol. 1, no. 139, (2012).

[12] Y. Du and Y. Tang, "Study on the Development of O2O E-commerce Platform of China from the Perspective of Offline Service Quality”, International Journal of Business and Social Science, vol. 4, no. 5, (2014).

[13] A. Dumrongsiri, "A supply chain model with direct and retail channels", European Journal of Operational Research, vol. 3, no. 187, (2008).

[14] G. Ellison and S. F. Ellison, "Internet retail demand: Taxes, geography, and online-offline competition", National Bureau of Economic Research, vol. w12242, (2006).

[15] E. Garbarino, "Then and now: Reality and perceptions in the evolution of online and offline pricing", Working Paper. Weatherhead School of Management, Case Western Reserve University, (2006).

[16] D. Grewal, R. Janakiraman, K. Kalyanam, P. K. Kannan and B. Ratchford, "Strategic online and offline retail pricing: a review and research agenda", Journal of Interactive Marketing, vol. 2, no. 24, (2010).

[17] W. Hong, "Quanzhou Agricultural E-Commerce Platform Based on O2O Modes", 2013 International Workshop on Computer Science in Sports, (2013) August 1-2, Wuhan, China.

[18] H. C. Hsieh, Y. C. Chen and H. C. Lin, "More Precise: Stores Recommendation under O2O Commerce", International Journal of Computing and Digital Systems, vol. 2, no. 3, (2014).

[19] G. Hua, S. Wang and T. C. E. Cheng, "Price and lead time decisions in dual-channel supply chains", European Journal of operational research, vol. 1, no. 205, (2010).

[20] S. Huang, C. Yang and H. Liu, "Pricing and production decisions in a dual-channel supply chain when production costs are disrupted", Economic Modelling, vol. 30, (2013).

[21] S. Huang, C. Yang and X. Zhang, "Pricing and production decisions in dual-channel supply chains with demand disruptions", Computers \& Industrial Engineering, vol. 1, no. 62, (2012).

[22] J. Snoek and B. Rund, "European B2C E-commerce Report, (2014), Available from: http://www.adigital.org/sites/default/files/studies/european-b2c-ecommerce-report-2014.

[23] W. Ma, Z. Zhao and H. Ke, "Dual-channel closed-loop supply chain with government consumptionsubsidy", European Journal of Operational Research, vol. 2, no. 226, (2013).

[24] S. K. Mukhopadhyay, X. Zhu and X. Yue, "Optimal contract design for mixed channels under information asymmetry", Production and Operations Management, vol. 6, no. 17, (2008).

[25] J. K. Ryan, D. Sun and X. Zhao, "Coordinating a Supply Chain with a Manufacturer-Owned Online Channel: A Dual Channel Model under Price Competition", IEEE Transactions on Engineering Management, vol. 2, no. 60, (2013).

[26] D. Scarpi, G. Pizzi and M. Visentin, "Shopping for fun or shopping to buy: Is it different online and offline?", Journal of Retailing and Consumer Services, vol. 3, no. 21, (2014).

[27] T.-M. Tsai and P.-C. Yang, "Pilot Study toward Realizing Social Effect in O2O Commerce Services", Social Informatics, Springer International Publishing, (2013).

[28] A. A. Tsay and N. Agrawal, "Channel Conflict and Coordination in the E-Commerce Age", Production and Operations Management, vol. 1, no. 13, (2004).

[29] A. A. Tsay and N. Agrawal, "Channel dynamics under price and service competition", Manufacturing $\&$ Service Operations Management, vol. 4, no. 2, (2000).

[30] C.-H. Wu, "Price and service competition between new and remanufactured products in a two-echelon supply chain", International Journal of Production Economics, vol. 1, no. 140, (2012).

[31] G. Xu, B. Dan and X. Zhang, "Coordinating a dual-channel supply chain with risk-averse under a twoway revenue sharing contract", International Journal of Production Economics, vol. 1, no. 147, (2014).

[32] R. Yan and Z. Pei, "Retail services and firm profit in a dual-channel market", Journal of Retailing and Consumer Services, vol. 4, no. 16, (2009). 
[33] J. Zhao and M. Wang, "Investigation and Analysis of the Shenyang local O2O business model", International Conference on Mechatronics, Electronic, Industrial and Control Engineering, (2014a) November 15-17, Shenyang, China.

[34] S. Zhao and X. Zhang, "Research on the Development of Traditional Retail Trends Based on O2OWanda Group as an Example", 2014 International Conference of the Academy of International Business, (2014b) June 23-26, Vancouver, Canada.

\section{Author}

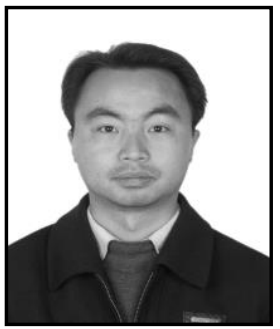

Jun Zhang, was born in Yunnan Province, China, 1977. He received his master's degree in Kunming University of Science and Technology, Kunming, China, 2005. Now he is a PhD Candidate in University of Electronic Science and Technology of China, Chengdu, China. His research interests include logistics management, supply chain management and e-commerce. 
International Journal of $u-$ and e- Service, Science and Technology Vol.8, No. 9 (2015) 